\title{
Effect of supplementing finishing pigs with different sources of chromium on performance and meat quality
}

\author{
Louise Manha Peres ${ }^{1}$, Ana Maria Bridi ${ }^{1}$, Caio Abércio da Silva ${ }^{1}$, Nayara Andreo ${ }^{1}$, Cátia Chilanti \\ Pinheiro Barata ${ }^{1}$, Julie Gabriela Nagi Dário ${ }^{1}$
}

${ }^{1}$ Universidade Estadual de Londrina, Londrina, PR, Brasil.

\begin{abstract}
The objective was to evaluate the dietary supplementation of different sources of chromium (inorganic: chromium sulfate and chelated: chromium-methionine) during the finishing period of pigs to obtain improvements in the animal performance, and carcass and meat quality. The statistical design was randomized blocks, where 44 barrows, with an initial weight $60.49 \pm 5.12 \mathrm{~kg}$, were divided into four blocks (heavier, heavy, light and lighter) according to initial weight. The experimental diets were isoenergetic and isonutrient, except for the chromium level. The treatments were divided as follows: control (without chromium), control $+200 \mathrm{ppb}$ of inorganic chromium (chromium sulfate), and control $+200 \mathrm{ppb}$ of chelated chromium (chromium-methionine). In the performance measures, the stall was considered the experimental unit and in the blood parameters, carcass and meat evaluations each animal constituted the experimental unit. Animals were slaughtered when they reached the final average weight of 107.23 $\pm 5.23 \mathrm{~kg}$. Blood samples were collected and tested for blood parameters (cholesterol, triglycerides and glucose) as well as carcass quality (hot and cold weights, yield, loin-eye area, muscle depth and backfat thickness) and meat quality (initial and final $\mathrm{pH}$, drip loss, color, chemical composition and lipid oxidation) parameters. Chromium-methionine supplementation provides a greater daily weight gain only compared with the animals that are not supplemented with chromium, because feed conversion is better as compared with the other treatments. After 24 hours of storage, the meat from pigs supplemented either with chromium-methionine or with chromium sulfate presents lower lipid oxidation than that from non-supplemented animals. However, after three days of storage, only chromim-methionine is effective in reducing lipid oxidation.
\end{abstract}

Key Words: chromium-methionine, daily weight gain, feed conversion ratio, glucose, inorganic chromium, lipid oxidation

\section{Introduction}

The low consumption of pork in Brazil as compared with other countries is due to prejudice, especially because consumers consider it a fat meat. Thus, the demand for leaner carcasses and meat goes against the preferences of the consumer market (Roppa, 2002).

An alternative to improve the quality of pig carcass and meat is through dietary supplementation of chromium (Spears, 2010).

The action of chromium in the animal metabolism induces maximization of the stimulus of glucose uptake by the cells of the target tissues due to the glucose tolerance factor (GTF) (Gomes et al., 2005). And the greater input of glucose into these cells is associated with an increased deposition of lean meat in the carcass by increasing muscle protein synthesis (Park et al., 2009).

Received July 8, 2013 and accepted April 15, 2014

Corresponding author: louise_mp@zootecnista.com.br

http://dx.doi.org/10.1590/S1516-35982014000700005

Copyright $@ 2014$ Sociedade Brasileira de Zootecnia. This is an Open Access article distributed under the terms of the Creative Commons Attribution Non-Commercial License, which permits unrestricted non-commercial use, distribution, and reproduction in any medium, provided the original work is properly cited.
Chromium appears in the animal diet in the inorganic form; however, this source presents low absorption by the animal organism (EFSA, 2012). This occurs because, during digestion, these compounds form insoluble complexes and can also adhere to the carbohydrates of the diet, preventing their absorption (Silva, 2007). Nonetheless, this absorption may be facilitated by other nutrients such as the amino acids methionine and histidine and vitamin $\mathrm{C}$ (Garcia and Garns, 2004).

Metal ions bind chemically to an organic molecule forming structures with unique characteristics of stability and high bioavailability (AAFCO, 1997). Therefore, the chelated minerals present increased bioavailability as compared with inorganic minerals.

Because of these characteristics, chromium influences the animal performance positively by improving weight gain, in addition to its effects on meat quality by reducing lipid oxidation, as it acts in the "control" of the formation of free radicals (Preuss et al., 1997).

The objective of this study was to evaluate the effects of dietary supplementation of different chromium sources for finishing pigs aiming to improve animal performance and carcass and meat quality. 


\section{Material and Methods}

This experiment was approved by the Ethics Committee on Animal Use (protocol number: 4072.2012.63) on May 8th, 2012.

The experiment was conducted at the Pig Production Sector of Fazenda Escola and at the Laboratory of Analysis of Animal-Origin Products of Universidade Estadual de Londrina.

The experimental design was completely randomized. Forty-four barrows with an initial body weight of $60.49 \pm 5.12 \mathrm{~kg}$ were used, and due to the variation in body weight at the beginning of the experiment, they were divided into four groups (heavier, heavy, light and lighter animals) and at the end of the experiment they were slaughtered with a final average body weight of $107.23 \pm 5.23 \mathrm{~kg}$.

The animals were subjected to three treatments during the finishing phase: a control diet without the addition of chromium; a control diet with inclusion of $200 \mathrm{ppb}$ of chromium sulphate (inorganic source); and a control diet with inclusion of $200 \mathrm{ppb}$ of chromium-methionine (chelated source).

In the performance analyses, the stall was considered the experimental unit, with the treatments without addition of chromium and with inclusion of chromium-methionine consisting of seven stalls with two pigs and one stall with only one animal, and the treatment with chromium sulphate consisted of six stalls with two pigs and two stalls with only one animal, totaling 24 stalls, 44 animals and eight repetitions per treatment. In the assessments of blood parameters, carcass and meat, each animal consisted of one experimental unit, so the number of repetitions for the diets without addition of chromium, with inclusion of chromium sulphate, and with inclusion of chromium-methionine were 15,14 and 15 , respectively.

The experimental diets (Table 1) given to the animals were isoenergetic and isonutrient except for the micromineral chromium, and they were formulated so as to meet the minimum nutritional requirements established by the Brazilian Tables for Poultry and Swine (Rostagno et al., 2011).

To provide the amount of $200 \mathrm{ppb}$ of chromium to the supplemented animals the total diet to be provided was calculated according to the used source. The daily weight gain, the daily feed intake and the feed conversion of the animals were measured to evaluate their performance.

To measure cholesterol, triglycerides and blood glucose during the performance evaluation, the pigs were feed-deprived for approximately 12 hours, and a sample of $5 \mathrm{~mL}$ of blood was collected from each animal in tubes without anticoagulant for cholesterol and triglycerides, and with anticoagulant (fluoride) for glucose at the beginning and end of the experiment.

Cholesterol, triglycerides and glucose were determined according to the following methods: GPO-PAP enzymatic colorimetric, enzymatic colorimetric with lipid clearing factor (LCF) and GPO-PAP enzymatic colorimetric, respectively, using an Ebram kit on a HITACHI 911 device.

The diet was withdrawn approximately seven hours before the departure of the animals, which were fed only water until the slaughter.

The animals were conducted with a handling board to the truck and transported to the slaughterhouse one day before the slaughter in the late afternoon due to the milder ambient temperature.

The pigs were slaughtered at a commercial abattoir in the city of Rolândia - PR. The slaughter procedures complied with the current legislation, according to Humane Slaughter (Brasil, 2000). The slaughter was preceded by stunning via electrical current, using a Petrovina ${ }^{\circledR}$ IS 2000 with two electrodes, applying 350 volts and 1.3 amperes for three seconds.

Table 1 - Percentage, chemical and energetic composition of the experimental diets in the finishing phase

\begin{tabular}{|c|c|c|c|}
\hline Ingredients $(\%)$ & Without Cr & $\begin{array}{c}200 \mathrm{ppb} \\
\text { inorganic } \mathrm{Cr}^{1}\end{array}$ & $\begin{array}{c}200 \mathrm{ppb} \\
\text { chelated } \mathrm{Cr}^{2}\end{array}$ \\
\hline Maize & 77.43 & 77.43 & 77.43 \\
\hline Soybean meal $45 \%$ & 20.08 & 20.08 & 20.08 \\
\hline Dicalcium phosphate & 0.87 & 0.87 & 0.87 \\
\hline Limestone & 0.59 & 0.59 & 0.59 \\
\hline Salt & 0.33 & 0.33 & 0.33 \\
\hline L-lysine HCL 98\% & 0.32 & 0.32 & 0.32 \\
\hline Premix $^{3}$ & 0.3 & 0.3 & 0.3 \\
\hline DL-methionine & 0.08 & 0.08 & 0.08 \\
\hline Inert & 0.00002 & 0.00 & 0.00 \\
\hline Chromium & 0.00 & 0.00002 & 0.00002 \\
\hline Total (\%) & 100.00 & 100.00 & 100.00 \\
\hline \multicolumn{4}{|l|}{ Calculated values } \\
\hline Calcium $(\%)$ & 0.51 & 0.51 & 0.51 \\
\hline Metabolizable energy (Mcal/kg) & g) 3.23 & 3.23 & 3.23 \\
\hline Crude fiber (\%) & 2.57 & 2.57 & 2.57 \\
\hline Available P (\%) & 0.25 & 0.25 & 0.25 \\
\hline Total P $(\%)$ & 0.46 & 0.46 & 0.46 \\
\hline Fat $(\%)$ & 3.03 & 3.03 & 3.03 \\
\hline Total lysine (\%) & 0.94 & 0.94 & 0.94 \\
\hline Total methionine + cystine $(\%)$ & 0.56 & 0.56 & 0.56 \\
\hline Total methionine $(\%)$ & 0.32 & 0.32 & 0.32 \\
\hline Crude protein $(\%)$ & 15.53 & 15.53 & 15.53 \\
\hline Sodium (\%) & 0.16 & 0.16 & 0.16 \\
\hline Total tryptophan (\%) & 0.17 & 0.17 & 0.17 \\
\hline
\end{tabular}

${ }^{1}$ Chromium sulfate.

${ }^{2}$ Chromium-methionine.

${ }^{3}$ Vitamin A - 720,000 IU; vitamin D3 - 144,000 IU; vitamin E - 2,400 IU; vitamin K3 - $216 \mathrm{mg}$, vitamin B1 - $96 \mathrm{mg}$, vitamin B2 - $456 \mathrm{mg}$, vitamin B6 - $96 \mathrm{mg}$, vitamin $\mathrm{B} 12-1,680 \mathrm{mcg}$, niacin - 2,400 mg, pantothenic acid - 1,560 mg, folic acid - $60 \mathrm{mg}$, manganese - 5,400 mg; zinc - $13.50 \mathrm{~g}$, iron - $10.50 \mathrm{~g}$, copper - 2,100 mg, iodine $-150 \mathrm{mg}$, selenium $-72 \mathrm{mg}$, zinc bacitracin $-3,350 \mathrm{mg}$. 
Bleeding was performed by sectioning the major vessels with the animals in the upright position, suspended by the hind limb.

In the slaughter line, subsequent to bleeding, the carcasses were scalding, cleaned, eviscerated, and sectioned lengthwise, and then weighed immediately after slaughter for obtaining hot carcass weight.

The carcasses were chilled for 24 hours at $2 \pm 2{ }^{\circ} \mathrm{C}$ and weighed to determine the cold carcass weight. Afterwards, the carcass was evaluated according to ABCS (1973).

It was possible to determine the carcass yield through the values of hot carcass weight compared with the live weight at slaughter, as cited by Bridi and Silva (2009).

The $\mathrm{pH}$ of the left half of each carcass was measured with the use of a potentiometer Testo, model 205, inserting it into the longissimus dorsi muscle between the penultimate and last ribs, in periods of 45 minutes after slaughter and 24 hours of carcass chilling to determine the initial and final $\mathrm{pH}$, respectively.

The left halves of the carcasses were sectioned between the last thoracic vertebra and the first lumbar to determine the loin-eye area, followed by the measurement of depth of the longissimus dorsi and fat thickness at $6 \mathrm{~cm}$ of the midline section, according to AMSA (2001).

At the end of the carcass evaluation, a piece of $30 \mathrm{~cm}$ in length of the longissimus dorsi muscle of each left half of the carcasses was removed, identified, packaged and transported in coolers to the laboratory for further analyses.

At the laboratory, the longissimus dorsi muscle was divided into three samples in the caudal-cranial direction. First: color and drip loss; second: lipid oxidation; and third: chemical composition of the meat. The samples of color, drip loss and lipid oxidation at 24 hours were subjected to laboratory analysis 24 hours after slaughter of animals and the remaining samples were packed in plastic bags and frozen for later analysis. The color was tested using a Minolta ${ }^{\circledR}$ portable colorimeter (model CR-10 colorimeter with illuminant $\mathrm{C}$ and $8^{\circ}$ angle of inclination - Tokyo, JP) and the components $\mathrm{L}^{*}$ (lightness), a* (red-green component) and $\mathrm{b}^{*}$ (yellow-blue component) were determined in accordance with the CIELAB system.

The drip loss was determined according to the technique described by Boccard et al. (1981).

For the assessment of lipid oxidation, the thiobarbituric acid reactive substances (TBARS) method was used, according to Pikul et al. (1989).

For the chemical composition, the AOAC (1995) method was used to obtain values in percentage of ash, protein and ether extract on a dry matter basis.

The results were subjected to analysis of variance and comparison of means by Tukey's test, using SAEG (Sistema de Análises Estatísticas e Genéticas, version 9.1).

\section{Results and Discussion}

There was no statistical difference between the treatments (Table 2) for the initial and final weights of the animals and the daily feed intake.

Lien et al. (2001) observed that the supplementation of 200 and $400 \mathrm{ppb}$ of chromium picolinate increased the daily feed intake, unlike the observed in this study, in which no difference was found between the same treatments.

Almeida et al. (2010) found that the supplementation of $400 \mathrm{ppb}$ of chromium-methionine did not influence any performance parameters other than the daily feed intake, which reduced. However, Park et al. (2009) found no difference in daily feed intake between animals supplemented with inorganic chromium (chromium sulfate) and those supplemented with chelated chromium (chromiummethionine), which is similar to the results observed in the present study.

The daily weight gain only differed between the treatments without supplementation of chromium and supplementation with chromium of chelated source (chromium-methionine). The chelated chromium supplementation provided the best feed conversion as compared with the other treatments.

Recent studies indicate that the use of inorganic or chelated chromium supplementation for pigs is contradictory.

Table 2 - Means and coefficients of variation observed for performance variables in pigs supplemented with inorganic or chelated chromium in the finishing phase

\begin{tabular}{|c|c|c|c|c|c|}
\hline & Without Cr & $200 \mathrm{ppb}$ inorganic $\mathrm{Cr}^{1}$ & $200 \mathrm{ppb}$ chelated $\mathrm{Cr}^{2}$ & Significance & $\mathrm{CV}(\%)$ \\
\hline Initial weight (kg) & 60.33 & 60.99 & 60.20 & NS & 3.47 \\
\hline Final weight (kg) & 106.84 & 107.36 & 107.50 & NS & 4.28 \\
\hline Daily feed intake (kg) & 3.17 & 3.13 & 3.11 & NS & 6.07 \\
\hline Daily weight gain (kg) & $1.13 b$ & $1.12 \mathrm{ab}$ & $1.19 \mathrm{a}$ & 0.008 & 5.03 \\
\hline Feed conversion ratio & $2.80 \mathrm{~b}$ & $2.79 \mathrm{~b}$ & $2.61 \mathrm{a}$ & 0.010 & 5.62 \\
\hline
\end{tabular}

Different letters in the same row mean significant difference by Tukey's test $(\mathrm{P}<0.05)$.

NS - not significant $(\mathrm{P}>0.05)$; CV $(\%)$ - coefficient of variation.

${ }^{1}$ Chromium sulfate.

${ }^{2}$ Chromium-methionine. 
Khajarern et al. (2006) did not find any improvement in the performance of pigs under supplementation of 200 and $400 \mathrm{ppb}$ of chromium bisglycinate-nicotinamide. Page et al. (1993) found that the supplementation of $200 \mathrm{ppb}$ of chromium chloride or of $1,467 \mathrm{ppb}$ of chromium picolinate improved average daily weight gain in the control group. To Park et al. (2009) the supplementation of $200 \mathrm{ppb}$ of chromium-methionine improved the weight gain as compared with the control treatments (without chromium) and with supplementation of $200 \mathrm{ppb}$ of chromium chloride.

Therefore, the weight gain of pigs supplemented with chromium influences the development of the muscle tissues (Park et al., 2009) due to the increase in the uptake of glucose by insulin sensitive cells, and this additional energy is fuel for protein synthesis, providing support to the tissue growth (muscle) and to the cell maintenance (Anderson and Kolozlovsky, 1985).

There was no statistical difference in the levels of cholesterol and triglycerides among the treatments performed at the beginning and end of the experiment (Table 3).

This is a contradiction, since the chromium should act on the lipid metabolism by increasing the activity of the lipoprotein lipase enzyme, reducing total cholesterol and triglycerides (Amoikon et al., 1995).

Marangon and Fernandes (2005) revealed that only the animals that did not receive chromium supplementation, either in inorganic or chelated form, had increased levels of cholesterol and triglycerides at the end of the experimental period, since elevated cholesterol and triglycerides are typical symptoms of chromium deficiency in mammals.

A significant difference in the level of final blood glucose was found between the unsupplemented group and the animals supplemented with inorganic or chelated chromium. The pigs supplemented with chromium sulfate or chromium-methionine presented a decrease in their final blood glucose (Table 3 ).

The reduction in plasma glucose level can be explained by the activation of the glucose tolerance factor (GTF) in the presence of chromium in the cytosol, strengthening the action of the insulin due to the maximization of the fluidity of the cell membrane. This increased the sensitivity of the cell to glucose (Evans and Bowman, 1992), resulting in a reduction of plasma glucose concentration.

No significant statistical difference was found between the treatments when hot carcass weight and cold carcass weight were analyzed. Consequently, the carcass yield followed the same behavior (Table 4).

Lindemann et al. (1995), Lien et al. (2001), Xi et al. (2001), and Ohh and Lee (2005) found positive effects of chromium supplementation on pig carcass traits, unlike Mooney and Cromwell (1995), Mooney and Cromwell (1997), Lima and Guidoni (1999), and Almeida et al. (2010), who demonstrated that there is no effect of chromium-methionine on the carcass traits of pigs.

The lack of statistical difference in the hot and cold carcass weights and carcass yield is probably due to the final live weight, which did not differ among treatments,

Table 3 - Means and coefficients of variation observed for blood parameters in pigs supplemented with inorganic or chelated chromium in the finishing phase

\begin{tabular}{|c|c|c|c|c|c|}
\hline & Without $\mathrm{Cr}$ & 200 ppb inorganic $\mathrm{Cr}^{1}$ & 200 ppb chelated $\mathrm{Cr}^{2}$ & Significance & $\mathrm{CV}(\%)$ \\
\hline Initial cholesterol (mg/dL) & 87.36 & 93.07 & 93.93 & NS & 11.72 \\
\hline Final cholesterol (mg/dL) & 107.5 & 110.36 & 113.43 & NS & 10.37 \\
\hline Initial triglycerides $(\mathrm{mg} / \mathrm{dL})$ & 51.67 & 48.64 & 58.27 & NS & 34.37 \\
\hline Final triglycerides $(\mathrm{mg} / \mathrm{dL})$ & 115.70 & 96.75 & 95.80 & NS & 26.87 \\
\hline Initial glucose (mg/dL) & 98.20 & 99.79 & 102.13 & NS & 12.44 \\
\hline Final glucose (mg/dL) & $103.58 b$ & $94.82 \mathrm{a}$ & $94.78 \mathrm{a}$ & 0.030 & 8.68 \\
\hline
\end{tabular}

Different letters in the same row mean significant difference by Tukey's test $(\mathrm{P}<0.05)$.

NS - not significant $(\mathrm{P}>0.05) ; \mathrm{CV}$ - coefficient of variation.

${ }^{1}$ Chromium sulfate.

${ }^{2}$ Chromium-methionine.

Table 4 - Means and coefficients of variation observed for carcass and muscle parameters in pigs supplemented with inorganic or chelated chromium in the finishing phase

\begin{tabular}{|c|c|c|c|c|c|}
\hline & Without $\mathrm{Cr}$ & $200 \mathrm{ppb}$ inorganic $\mathrm{Cr}^{1}$ & $200 \mathrm{ppb}$ chelated $\mathrm{Cr}^{2}$ & Significance & $\mathrm{CV}(\%)$ \\
\hline Hot carcass weight (kg) & 81.04 & 80.54 & 80.91 & NS & 3.80 \\
\hline Cold carcass weight $(\mathrm{kg})$ & 78.73 & 78.98 & 78.82 & NS & 4.41 \\
\hline Carcass yield (\%) & 75.73 & 75.39 & 75.39 & NS & 1.93 \\
\hline Loin-eye area $\left(\mathrm{cm}^{2}\right)$ & 41.18 & 40.63 & 41.20 & NS & 10.87 \\
\hline Muscle depth (mm) & 61.06 & 60.84 & 61.15 & NS & 8.68 \\
\hline Backfat thickness (mm) & 15.59 & 15.50 & 14.99 & NS & 20.77 \\
\hline
\end{tabular}

NS - not significant $(\mathrm{P}>0.05)$; $\mathrm{CV}$ - coefficient of variation.

${ }^{1}$ Chromium sulfate.

${ }^{2}$ Chromium-methionine. 
and this possibly also influenced the results of the loin-eye area, muscle depth and backfat thickness (Table 4).

The initial and final $\mathrm{pH}$ were not affected by the treatments (Table 5), which is consistent with Matthews et al. (2003) and Matthews et al. (2005), who supplemented pigs with chromium picolinate, and Toghyani et al. (2008), who evaluated chicken meat. They also found no difference in the $\mathrm{pH}$ when using treatments with inorganic or chelated chromium.

There was no statistical difference in drip loss among the three treatments (Table 5). Boleman et al. (1995) and Jackson et al. (2009) also observed no significant difference in drip loss when pigs were supplemented with chromium. However, O'Quinn et al. (1998) and Matthews et al. (2005) observed that chelated-chromium supplementation improved the water-retention capacity.

The color variable was not influenced by the different treatments (Table 5). The results were similar to those found by Matthews et al. (2005) and Almeida et al. (2010), who evaluated the use of chelated chromium.

The $\mathrm{pH}$ influences drip loss and color. There is an inverse relationship between $\mathrm{pH}$ and drip loss, because as the $\mathrm{pH}$ decreases, the drip loss increases due to denaturation of muscle proteins with consequent changes in cell membrane permeability (Hertog-Meischke et al., 1997). The drip loss influences color variation.

Thus, it can be stated that because of the lack of difference in initial $\mathrm{pH}$ among treatments, the drip loss and the color of the evaluated meats could not present any difference among them.

There was no statistical difference among the treatments regarding the proximate composition of meats (Table 5). Mooney and Cromwell (1997) and Van Ligt et al. (2002) also observed that dry matter, ash, protein and ether extract did not differ among treatments.

However, Boleman et al. (1995) reported that animals fed chromium picolinate had their body fat percentage reduced. These results are in accordance with the expected effect of chromium, which is an increase in the amount of lean carcass at the expense of a decrease in the fat percentage. This is explained by the chromium ability to promote increased glucose uptake by the target cells, preventing the excess of plasmatic glucose, which can be converted into fat (Gomes et al., 2005).

The chromium supplementation was effective in reducing lipid oxidation in both chilling periods (Table 6). After 24 hours of chilling it was found that the meat from animals without supplementation of chromium proved more oxidized than the meat from animals supplemented with inorganic or chelated chromium, which did not differ between them. Regarding the meat that kept refrigerated for three days, it was possible to prove continuity of the positive effect of chelated chromium in reducing lipid oxidation, which differed from the control group, but not from the group supplemented with inorganic chromium. However, after three days of refrigeration, lipid oxidation

Table 5 - Means and coefficients of variation observed for initial $\mathrm{pH}$, drip loss, color and chemical parameters in meat from pigs supplemented with inorganic or chelated chromium in the finishing phase

\begin{tabular}{|c|c|c|c|c|c|}
\hline & Without Cr & $200 \mathrm{ppb}$ inorganic $\mathrm{Cr}^{1}$ & $200 \mathrm{ppb}$ chelated $\mathrm{Cr}^{2}$ & Significance & $\mathrm{CV}(\%)$ \\
\hline Initial $\mathrm{pH}$ & 6.39 & 6.45 & 6.33 & NS & 3.70 \\
\hline Final $\mathrm{pH}$ & 5.74 & 5.73 & 5.74 & NS & 1.53 \\
\hline Drip loss $(\%)$ & 1.14 & 0.88 & 0.96 & NS & 59.27 \\
\hline Lightness (L*) & 55.05 & 54.76 & 55.45 & NS & 5.23 \\
\hline Red intensity $\left(a^{*}\right)$ & 4.77 & 4.07 & 3.74 & NS & 40.24 \\
\hline Yellow intensity $\left(b^{*}\right)$ & 10.70 & 10.35 & 10.62 & NS & 13.04 \\
\hline Dry matter & 26.23 & 26.29 & 26.49 & NS & 3.96 \\
\hline Ash & 0.96 & 1.00 & 0.95 & NS & 13.06 \\
\hline Crude protein & 23.57 & 24.16 & 23.80 & NS & 7.81 \\
\hline Ether extract & 1.87 & 1.70 & 1.67 & NS & 38.06 \\
\hline
\end{tabular}

NS - not significant $(\mathrm{P}>0.05)$; $\mathrm{CV}$ - coefficient of variation.

${ }^{1}$ Chromium sulfate.

${ }^{2}$ Chromium-methionine.

Table 6 - Means and coefficients of variation observed for lipid oxidation (TBARS) of meat samples from pigs supplemented with inorganic or chelated chromium during finishing and stored in a refrigerator for 24 or 72 hours after slaughter

\begin{tabular}{|c|c|c|c|c|c|}
\hline \multirow{2}{*}{ Storage time } & Without $\mathrm{Cr}$ & $200 \mathrm{ppb}$ inorganic $\mathrm{Cr}^{1}$ & $200 \mathrm{ppb}$ chelated $\mathrm{Cr}^{2}$ & \multirow{2}{*}{ Significance } & \multirow{2}{*}{$\mathrm{CV}(\%)$} \\
\hline & \multicolumn{3}{|c|}{$\mathrm{mg}$ of malonaldehyde $/ \mathrm{kg}$ of sample } & & \\
\hline 24 hours & $0.09 \mathrm{~b}$ & $0.05 \mathrm{a}$ & $0.06 \mathrm{a}$ & 0.022 & 39.35 \\
\hline 72 hours & $0.43 b$ & $0.36 \mathrm{ab}$ & $0.32 \mathrm{a}$ & 0.004 & 18.75 \\
\hline
\end{tabular}

Different letters in the same row mean significant difference by Tukey's test $(\mathrm{P}<0.05)$.

NS - not significant $(\mathrm{P}>0.05) ; \mathrm{CV}$ - coefficient of variation.

${ }^{1}$ Chromium sulfate.

${ }^{2}$ Chromium-methionine. 
in the inorganic chromium group did not differ from the control group.

In this study it was found that the glucose level in the group of animals which were not supplemented with chromium was the highest. The sharp metabolism of glucose under hyperglycemia is usually associated with the high formation of free radicals (Schneider and Oliveira, 2004).

The formation of free radicals arises from AGE (advanced glycation end-products) formed during the glycation, wherein the excess sugar molecule adheres to one molecule of protein (collagen, elastin, among others), originating the free radicals. The AGE are a "sugar-protein" complex which form free radicals, thereby triggering the oxidative stress, as they have the capacity to modify the chemical and functional properties of various biological structures (Bierhaus et al., 1998; Jakus and Rietbrock, 2004).

Chromium, associated with other molecules, acts in the form of an organic complex called the glucose tolerance factor, presenting an effect of amplification of the insulin signal (Schwartz and Mertz, 1959).

One possible explanation for the chrome effect in reducing lipid oxidation in meat from animals supplemented with this mineral is that the potentiation of the insulin reduces the excess of circulating glucose. Consequently, a smaller amount of AGE is formed, resulting in fewer free radicals acting on the biological structures, thereby minimizing the susceptibility to lipid oxidation of these meats.

\section{Conclusions}

Supplementation of chromium-methionine for finishing pigs provides a greater daily weight gain as compared with no supplementation, because feed conversion is improved. Regardless of the source, chromium provides a reduction in the lipid oxidation of meats.

\section{Acknowledgments}

The authors thank CNPq (Conselho Nacional de Desenvolvimento Científico e Tecnológico) for having funded this project.

\section{References}

AAFCO - Association of American Feed Control Official. 1997. Official publication. Atlanta, GA.

ABCS - Associação Brasileira de Criadores de Suínos. 1973. Métodos brasileiro de classificação de carcaças. 2.ed. ABCS, Estrela.

Almeida, V. V.; Berenchtein, B.; Costa, L. B.; Tse, M. L. P.; Braz, D. B. and Miyada, V. S. 2010. Ractopamina, cromo-metionina e suas combinações como aditivos modificadores do metabolismo de suínos em crescimento e terminação. Revista Brasileira de Zootecnia 39:1969-1977.

Amoikon, E. K.; Fernandez, J. M.; Southern, L. L.; Thompson Jr., D. L.; Ward, T. L. and Olcott, B. M. 1995. Effect of chromium tripicolinato on growth, glucose tolerance, insulin sensitivity, plasma metabolites, and growth hormone in pigs. Journal of Animal Science 73:1123-1130.

AMSA - American Meat Science Association. 2001. Handbook meat evaluation. University of Wyoming, Laramie.

Anderson, R. A. and Kolozlovsky, A. S. 1985. Chromium intake, absorption and excretion of subjects consuming self-selected diets. American Journal of Clinical Nutrition 41:1177-1183.

AOAC - Association of Official Analytical Chemistry. 1995. Official methods of analysis. 16th ed. AOAC International, Arlington, VA.

Bierhaus, A.; Hofman, M. A.; Ziegler, R. and Nawroth, P. P. 1998. AGEs and their interaction with AGE-receptors in vascular disease and diabetes mellitus. I. The AGE concept. Cardiovascular Research 37:586-600.

Boccard, R.; Buchter, L.; Casteels, E.; Cosentino, E.; Dransfield, E.; Hood, D. E.; Joseph, R. L.; Macdougall, D. B.; Rhodes, D. N.; Schön, I.; Tinbergen, B. J. and Touraille, C. 1981. Procedures for measuring meat quality characteristics in beef production experiments. Report of a working group in the Commission of the European Communities' (CEC) beef production research programme. Livestock Production Science 8:385-397.

Boleman S. L.; Boleman, S. J.; Bidner, T. D.; Southern, L. L.; Ward, T. L.; Pontif, J. E. and Pike M. M. 1995. Effect of chromium picolinate on growth, body composition, and tissue accretion in pigs. Journal of Animal Science 73:2033-2042.

Brasil. Ministério da Agricultura, Pecuária e Abastecimento. 2000. Instrução Normativa n. 3, de 17 de Janeiro de 2000. Aprovar o regulamento técnico de métodos de insensibilização para o abate humanitário de animais de açougue. Available at: $<$ http://extranet. agricultura.gov.br/sislegis/action/detalhaAto.do?method=consulta rLegislacaoFederal>. Accessed on: Apr. 20, 2013.

Bridi, A. M. and Silva, C. A. 2009. Avaliação da carne suína. 2.ed. Midiograf, Londrina.

EFSA - European Food Safety Authority. 2012. Scientific Opinion on ChromoPrecise ${ }^{\circledR}$ cellular bound chromium yeast added for nutritional purposes as a source of chromium in food supplements and the bioavailability of chromium from this source. European Food Safety Authority Journal 10:1-27.

Evans, G. W. and Bowman, T. D. 1992. Chromium picolinate increases membrane fluidity and rate of insulin internalization. Journal of Inorganic Biochemistry 46:243-250.

Garcia, A. G. and Garns, P. M. 2004. Papel del cromo y del cinc en el metabolismo de la insulina. Revista Médica Del Instituto Mexicano Del Seguro Social 42:347-352.

Gomes, M. R.; Rogero, M. M. and Tirapegui, J. 2005. Considerações sobre cromo, insulina e exercício físico. Revista Brasileira Medicina do Esporte 11:262-266.

Hertog-Meischke, M. J. A.; Laack, R. J. L. M. and Smulders, F. J. M. 1997. The waterholding capacity of fresh meat. The Veterinary Quartely 19:175-181.

Jackson, A. R.; Powell, S.; Johnston, S. L.; Matthews, J. O.; Bidner, T. D.; Valdez, F. R. and Southern, L. L. 2009. The effect of chromium as chromium propionate on growth performance, carcass traits, meat quality, and the fatty acid profile of fat from pigs fed no supplemented dietary fat, choice white grease, or tallow. Journal of Animal Science 87:4032-4041.

Jakus, V. and Rietbrock, N. 2004. Advanced glycation end products and the progress of diabetic vascular complications. Physiological Research 53:131-142.

Khajarern, J.; Khajaren, S.; Ashmead, H. D. and Ashmead, S. D. 2006. The effect of chromium bisglycinate-nicotinamide chelate 
supplementation on growth and carcass quality in growing and finishing pigs. International Journal of Applied Research in Veterinary Medicine 4:193-199.

Lien, T. F.; Wu, C. P.; Wang, B. J.; Shiao, M. S.; Shiao, T. Y.; Lin, B. H.; Lu, J. J. and Hu, C. Y. 2001. Effect of supplemental levels of chromium picolinate on the growth performance, serum traits, carcass characteristics and lipid metabolism of growing-finishing pigs. Animal Science 72:289-296.

Lima, G. L. M. M. and Guidoni, A. L. 1999. Níveis de cromo-ácido nicotínico em dietas de suínos em crescimento e terminação. Pesquisa Agropecuária Brasileira 34:433-439.

Lindemann, M. D.; Wood, C. M.; Harper, A. F.; Kornegay, E. T. and Anderson, R. A. 1995. Dietary chromium picolinate additions improve gain:feed and carcass characteristics in growing-finishing pigs and increase litter size in reproducing sows. Journal of Animal Science 73:457-465.

Marangon, A. F. C. and Fernandes, L. G. M. 2005. O uso do picolinato de cromo como coadjuvante no tratamento da diabetes mellitus. Ciência da Saúde 3:253-260.

Matthews, J. O.; Higbie, A. D.; Southern, L. L.; Coombs, D. F.; Bidner, T. D. and Odgaard, R. L. 2003. Effect of chromium propionate and metabolizable energy on growth, carcass traits, and pork quality of growing-finishing pigs. Journal of Animal Science 8:191-196.

Matthews, J. O.; Guzik, A. C.; Lemieux, F. M.; Southern, L. L. and Bidner, T. D. 2005. Effects of chromium propionate on growth, carcass traits, and pork quality of growing-finishing pigs. Journal of Animal Science 83:858-862

Mooney, K. W. and Cromwell, G. L. 1995. Effects of dietary chromium picolinate supplementation on growth, carcass characteristics, and accretion rates of carcass tissues in growing-finishing swine. Journal of Animal Science 73:3351-3357.

Mooney, K. W. and Cromwell, G. L. 1997. Efficacy of chromium picolinate and chromium chloride as potential carcass modifiers in swine. Journal of Animal Science 75:2661-2671.

O'Quinn, P. R.; Smith, J. W. I.; Owen, K. Q.; Blum, S. A.; Nelssen, J. L.; Tokach, M. D. and Goodband, R. D. 1988. Effects of source and level of added chromium on growth performance and carcass characteristics of growing-finishing pigs. Journal of Animal Science $76: 166-171$

Ohh, S. J. and Lee, J. Y. 2005. Dietary chromium-methionine chelate supplementation and animal performance. Journal of Animal Science 18:898-907.
Page, T. G.; Southern, L. L. and Ward, T. L. 1993. Effect of chromium picolinate on growing and serum and carcass traits of growingfinishing pigs. Journal of Animal Science 71:656-662.

Park, J. K.; Lee, J. Y.; Chae, B. J. and Ohh, S. J. 2009. Effects of different sources of dietary chromium on growth, blood profiles and carcass traits in growing-finishing pigs. Asian - Australasian Journal of Animal Sciences 22:1547-1554.

Pikul, J.; Leszcynski, D. E. and Kummerow, F. A. 1989. Evaluation of tree modified TBA methods for measuring lipid oxidation in chickens meat. Journal of Agriculture and Food Chemistry 37:1309-1313.

Preuss, H. G.; Grojec, P. L.; Lieberman, S. and Anderson, R. A. 1997. Effects of different chromium compounds on blood pressure and lipid peroxidation in spontaneously hypertensive rats. Clinical Nephrology 47:325-330.

Roppa, L. 2002. Carne suína: mitos e verdades. Available at: $<\mathrm{http}$ ://www.porkworld.com.br>. Accessed on: Apr. 30, 2013.

Rostagno, H. S.; Albino, L. F. T.; Donzele, J. L.; Gomes, P. C.; Oliveira, R. F.; Lopes, D. C.; Ferreira, A. S. and Barreto, S. L. T. 2011. Tabelas brasileiras para aves e suínos: composição de alimentos e exigências nutricionais. 3.ed. Universidade Federal de Viçosa, Viçosa, MG, Brasil.

Schneider, C. D. and Oliveira, A. R. 2004. Radicais livres de oxigênio e exercício: mecanismos de formação e adaptação ao treinamento físico. Revista Brasileira de Medicina do Esporte 10:308-313.

Schwarz, K. and Mertz, W. 1959. Chromium(III) and the glucose tolerance factor. Archives of Biochemistry and Biophysics 85:292-295.

Silva, L. M. G. S. 2007. Cromo na alimentação de frangos de corte. Dissertation (M.Sc.). Universidade Estadual de Maringá, Maringá.

Spears, J. 2010. Chromium in animal nutrition. Available at: $<\mathrm{http}: / /$ www.saltinstitute.org/wp-content/uploads/2013/09/1st-quarterSTM.pdf $>$. Accessed on: Feb. 5, 2014.

Toghyani, M.; Khodami, A. and Gheisari, A. A. 2008. Effect of organic and inorganic chromium supplementation on meat quality of heat-stressed broiler chicks. American Journal of Animal and Veterinary Sciences 3:62-67.

Van De Ligt, C. P. A.; Lindemann, M. D. and Cromwell, G. L. 2002. Assessment of chromium tripicolinate supplementation and dietary protein level on growth, carcass, and blood criteria in growing pigs. Journal of Animal Science 80:412-2419.

Xi, G.; Xu, Z.; Wu, S. H. and Shijiang, C. 2001. Effect of chromium picolinate on growth performance, carcass characteristics, serum metabolites and metabolism of lipid in pigs. Journal of Animal Science 14:258-262. 